\title{
Factors associated with overweight and obesity in Mexican school-age children: Results from the National Nutrition Survey 1999
}

Bernardo Hernández, D Sc, ${ }^{(1)}$ Lucía C uevas-N asu, BSc, (2) Teresa Shamah-Levy, BSc, ${ }^{(2)}$

Eric A Monterrubio, BSC, (2) Claudia Ivonne Ramírez-Silva, BSC, ${ }^{(2)}$ Raquel García-Feregrino, BSC, ${ }^{(2)}$

Juan A Rivera, MS, PhD, (2) Jaime Sepúlveda-A mor, MD, DSc.(3)

\begin{abstract}
Hernández B, Cuevas-Nasu L, Shamah-LevyT, Monterrubio EA, Ramírez-Silva CI, García-Feregrino R, Rivera JA, Sepúlveda-Amor J. Factors associated with overweight and obesity in Mexican school-age children: Results from the National Nutrition Survey 1999. Salud Publica Mex 2003;45 suppl 4:S551-S557. The English version of this paper is available too at: http://www.insp.mx/salud/index.html
\end{abstract}

\begin{abstract}
A bstract
Objective. The objective of the study was to measure the prevalence of overweight and obesity in Mexican schoolage children (5-11 years) in the National N utrition Survey 1999 (N N S-1999). Material and Methods 0 verweight and obesity (defined as an excess of adipose tissue in the body) were evaluated through the Body Mass Index (BMI) in 10,901 children, using the standard proposed by the International 0 besityTask Force. Sociodemographic variables were obtained using a questionnaire administered to the children's mothers. Results The national prevalence of overweight and obesity was reported to be $19.5 \%$. The highest prevalence figures were found in Mexico City $(26.6 \%)$ and the N orth region (25.6\%). W hen adjusting by region, rural or urban area, sex, maternal schooling, socioeconomic status, indigenous ethnicity and age, the highest prevalences of overweight and obesity were found among girls. The risks of overweight and obesity were positively associated with maternal schooling, children's age and socioeconomic status. Conclusions. 0 verweight and obesity are prevalent health problems in Mexican school-age children, particularly among girls, and positively associated with socioeconomic status, age, and maternal schooling. This is a major public health problem requiring preventive interventions to avoid
\end{abstract}

\author{
Hernández B, Cuevas-Nasu L, Shamah-LevyT, \\ Monterrubio EA, Ramírez-Silva Cl, \\ García-Feregrino R, Rivera JA, Sepúlveda-Amor J. \\ Factores asociados con sobrepeso y obesidad \\ en niños mexicanos de edad escolar: \\ resultados de la Encuesta Nacional de Nutrición, 1999. \\ Salud Publica Mex 2003;45 supl 4:S551-S557. \\ El texto completo en inglés de este artículo también \\ está disponible en: http://www.insp.mx/salud/index.html
}

\section{Resumen}

Objetivo. Documentar las prevalencias de sobrepeso y obesidad en niños mexicanos en edad escolar ( 5 a 11 años de edad) obtenidas de la Encuesta $\mathrm{N}$ acional de N utrición en 1999 (EN N -1999). Material y métodos. El sobrepeso y la obesidad (definida como un exceso de tejido adiposo en el organismo) se evaluaron a través del Indice de Masa Corporal (IMC) en 10901 niños, tomando como patrón de referencia el propuesto por el International 0 besity Task Force. Las variables socio demo gráficas se obtuvieron a partir de un cuestionario aplicado a la madre del niño. Resultados La prevalencia nacional de sobrepeso y obesidad fue de $19.5 \%$. Las prevalencias más altas se encontraron en la Ciudad de México (26.6\%) y en la región norte (25.6\%). Al ajustar por región, zona rural o urbana, sexo, escolaridad de la madre, nivel socioeconómico, edad e indigenismo, los mayores riesgos de sobrepeso y obesidad se encontraron en niñas; el riesgo de obesidad y sobrepeso se asoció positivamente con la escolaridad de la madre, con el nivel socio económico y con la edad de los escolares. Conclusiones El sobrepeso y obesidad son problemas de salud de alta prevalencia en niños en edad escolar en México, especialmente en niñas, y se asocia positivamente con el nivel socioeconómico, la edad de los escolares y la escolaridad de

This survey was conducted with the support from the Secretaría de Salud.

(1) Centro de Investigación en Salud Poblacional, Instituto Nacional de Salud Pública, Cuernavaca, Morelos, México.

(2) Centro de Investigación en $N$ utrición y Salud, Instituto $\mathrm{N}$ acional de Salud Pública, Cuernavaca, Morelos, México.

(3) Instituto Nacional de Salud Pública, Cuernavaca, Morelos, México.

Received on: A ugust 20,2002 • Accepted on: September 18, 2003

Address reprint requests to: D r. Bernardo Hernández, Director de Salud Reproductiva, Instituto N acional de Salud Pública. Avenida Universidad 655 , colonia Santa María A huacatitlán 62508 Cuernavaca, Morelos, México.

E-mail: bhernand@ correo.insp.mx 
future health consequences. The English version of this paper is available too at: http://www.insp.mx/salud/index.html

Key words: nutritional surveys; bo dy mass index; o verweight; obesity; school-age children; Mexico las madres. Este es un problema de salud pública que requiere acciones de prevención para evitar riesgos en la salud en un futuro. El texto completo en inglés de este artículo también está disponible en: http://www.insp.mx/salud/ index.html

Palabras clave: encuestas nutricionales; índice de masa corporal; so brepeso; o besidad; niños en edad escolar; México
0 besity, defined as an excess of adipose tissue in the body, is currently considered a public health problem worldwide. ${ }^{1,2-5}$ In Latin America, the prevalence of obesity has greatly increased in all population groups, particularly in low socioeconomic level populations. ${ }^{6-8}$ Women of reproductive age (12-49 years old) and children $<5$ years are two population groups with a high prevalence of obesity. ${ }^{9-10}$ Moreover, some countries have reported an increasing prevalence of obesity in those population groups in the last two decades. ${ }^{11-13}$

In Mexico, several studies have documented a high prevalence of overweight and obesity. ${ }^{90,10,14}$ The Mexico City Urban Food and Nutrition Survey (Encuesta Urbana de Alimentación y Nutrición en la Zona Metropolitana de la Ciudad de México or ENURBAL 1995) found a prevalence of overweight and obesity of $13.6 \%$ among children $<5$ years of age. ${ }^{15}$

Childhood obesity is a common nutrition problem -and therefore a public health problem-in developed countries. Obesity statistics are available in Mexico at the country level for children $<5$ years of age and women of childbearing age.,10,15 Although the precise prevalence of obesity in Mexican school-age children remains unknown, it is estimated to be high and is showing an upward trend. ${ }^{16}$ Available information on the prevalence of obesity in school-age children comes from small studies; for example, in two areas of Mexico City the prevalence of overweight and obesity among children aged $10-15$ years was approximately $24 \%$ in $1998 .{ }^{17}$

Further studies have documented an association between childhood obesity and the risk of adult obesity $^{18}$ as well as the risk of chronic diseases such as hypertension, diabetes (due to hyperinsulinemia), hypercholesterolemia, cardiovascular disease, and cancer. ${ }^{19-22}$

There is a dearth of information on the nutritional status of the school-age population at the country level. To fill this gap, this paper aims at documenting the prevalence of overweight and obesity in Mexican school-age children, as measured by the National Nutrition Survey 1999 (NNS-1999). This survey is representative at the country level and includes four regions and urban and rural areas of Mexico. The prevalence of obesity and its association with sociodemographic characteristics are analyzed to generate information that should be useful for designing nutrition programs and interventions to prevent obesity.

\section{Material and Methods}

\section{Population and sample size}

The study population consisted of Mexican school-age children aged 5-11 years. Data were collected through the NNS-1999 conducted from October 1998 to March 1999 and included a probabilistic sample representative of the four regions and urban and rural areas of Mexico (population over or under 2500 inhabitants).

The study sample was selected from the National Household Sampling Frame (Marco Muestral Nacional de Hogares) of the National Institute of Statistics, Geography, and Informatics (Instituto Nacional de Estadística, Geografía e Informática, INEGI), using a multistage, stratified, cluster sampling design.

The survey included 21000 households, from which 8200 had a 5- to 11-year-old school-age population currently living there. The non-response rate was $7.6 \%$ for this population group, leaving a sample of 11415 school-age children. Only school-age children of families who refused to participate were excluded.

\section{Study design}

A cross-sectional study was conducted to assess the prevalence of overweight and obesity and its association with sociodemographic characteristics in children aged 5-11 years. The Body Mass Index (BMI= weight $\mathrm{kg} /$ height $\mathrm{m}^{2}$ ) was utilized to measure the dependent variables for overweight and obesity. To classify children as being overweight or obese, we used the age 
and sex specific cutoff points proposed by Cole et al, as suggested by the International Obesity Task Force. ${ }^{23}$ These cutoff points are based on a reference population which includes data from different countries, and generates BMI-specific centiles for children linked to adult BMI cutoff points of $25 \mathrm{~kg} / \mathrm{m}^{2}$ (overweight) and $30 \mathrm{~kg} / \mathrm{m}^{2}$ (obesity).

The independent variables were residence region North (Baja California, Baja California Sur, Coahuila, Chihuahua, Durango, Nuevo León, Sonora, Tamaulipas), Center (Aguascalientes, Colima, Guanajuato, Jalisco, México (excluding suburban counties of Mexico City), Michoacán, Morelos, Nayarit, Querétaro, San Luis Potosí, Sinaloa, Zacatecas), Mexico City (Distrito Federal and suburban counties of Mexico City) and South (Campeche, Chiapas, Guerrero, Hidalgo, Oaxaca, Puebla, Quintana Roo, Tabasco, Tlaxcala, Veracruz, Yucatán), area (urban or rural), sex (male or female), father's literacy status (literate or illiterate according to reading and writing ability), maternal schooling (none, primary, secondary, high school, and higher education), indigenous ethnicity (12- to 49-yearold woman speaking a native language), and socioeconomic status index (constructed using principal component analysis with variables such as flooring materials, potable water, and ownership of appliances such as radio, television, refrigerator, washing machine, and stove), in accordance with the index proposed by Bronfman et al..$^{24}$

\section{Data collection and analysis}

Weight and height of participants were measured following the procedures recommended by Lohman. ${ }^{25}$ Anthropometrics were standardized using the method recommended by Habicht. ${ }^{26}$ Weight was measured with a digital-solar $150 \mathrm{~kg}$ scale (TANITA Corporation, model 1631, Made in China) and height with a 1-mmunit two-meter stadimeter (Stadimeter "DYNA TOP" S.A. de C.V. Model E-1. Made in Mexico).

Study subjects were weighed without shoes, wearing minimal clothing, standing straight up with heels together and tips apart and holding their arms motionless parallel to the body axis. Height was measured in the same position as for weight. The headpiece of the stadimeter was set at a $90^{\circ}$ angle on the top of the head of the individual. ${ }^{25}$ Experts conducted the training and standardization of interviewers and developed the survey questionnaires. Data were entered in an electronic database compiled in Clipper Version 5.2 at the National Institute of Public Health in Mexico (Instituto Nacional de Salud Pública). The database was then cleaned and observations with either missing weight and height values or implausible values were checked and corrected. Implausible anthropometric values were defined as BMI values $<10$ or $>38$. The final database contained all the study variables and included a sample of 10901 school-age children.

\section{A nalysis}

After exploratory data analysis, crude and adjusted odds ratios and relative risks with $95 \%$ confidence intervals were obtained, to identify risk factors associated with overweight and obesity. Logistic regression models were fitted with the following variables: sex, age, urban/rural area, region, indigenous ethnicity, socioeconomic status, maternal schooling, and father's literacy status. Additional models were fitted separately using either maternal schooling or the father's literacy to avoid collinearity problems. Since the odds ratio point estimates were similar to the relative risks for overweight and obesity, only the crude and adjusted odds ratios are presented in this paper. Stratified analysis was also performed by residence region to explore interactions between residence region and risk factors for overweight and obesity. Statistical analyses considered the stratified and cluster sampling design. The expansion factor was also included to consider the population distribution, using a complex survey analysis model with the Stata SVY module (Stata V. 7.0 and SPSS V. 10.0.0). ${ }^{27,28}$

\section{Results}

The prevalence of overweight and obesity was estimated in a sample of 10901 children aged 5-11 years from the NNS-1999. Mean age was $8.32 \pm 0.02$ years. Children were distributed by region as follows: $17.7 \%$ in the North region, $33.4 \%$ in the center, $15.3 \%$ in Mexico City, and $33.6 \%$ in the South region. The majority of children $(69.1 \%)$ lived in rural areas with $50.9 \%$ being female. There was a high percentage of literacy among fathers, while a greater percentage of mothers had only elementary schooling. In $10.7 \%$ of households at least one woman aged 12-49 years speaking a native language resided (Table I). The crude mean BMI was $17.18 \pm 4.55$ for the entire population $17.67 \pm 5.23$ for the north region, $17.09 \pm 3.88$ for the center, $17.57 \pm 5.01$ for Mexico City and 16.83 \pm 3.82 for the south region.

The nationwide prevalence of overweight and obesity in school-age children was 19.5\% (Table II). By applying the expansion factor to the study sample, it is estimated that there are 2919657 school-age children with overweight and obesity in Mexico. Mexico City and the North region had the highest prevalence 
Table I

\section{Characteristics of ChildRen 5-11 years of age from the National Nutrition Survey, Mexico, 1999*}

\begin{tabular}{|c|c|c|c|}
\hline \multirow{2}{*}{ Variable } & \multirow[b]{2}{*}{ Sample (n) } & \multicolumn{2}{|c|}{ Population estimate } \\
\hline & & n (thousands) & $\%$ \\
\hline \multicolumn{4}{|l|}{ Region } \\
\hline North & 3188 & 2657.4 & 17.7 \\
\hline Center & 3292 & 5001.4 & 33.4 \\
\hline Mexico City & 855 & 2287.0 & 15.3 \\
\hline South & 3566 & 5026.7 & 33.6 \\
\hline \multicolumn{4}{|l|}{ Area of residence } \\
\hline Rural & 4759 & 4633.0 & 30.9 \\
\hline Urban & 6142 & 10339.6 & 69.1 \\
\hline \multicolumn{4}{|l|}{ Sex } \\
\hline Male & 5396 & 7353.9 & 49.1 \\
\hline Female & 5505 & 7618.7 & 50.9 \\
\hline \multicolumn{4}{|l|}{ Father's literacy status } \\
\hline Illiterate & 1492 & 2037.8 & 13.6 \\
\hline Literate & 9409 & 12934.8 & 86.4 \\
\hline \multicolumn{4}{|l|}{ Maternal schooling } \\
\hline Elementary school & 5087 & 6368.6 & 42.5 \\
\hline Middle school & 1839 & 2880.5 & 19.2 \\
\hline High school or above & 1560 & 2763.6 & 18.5 \\
\hline No schooling & 2415 & 2959.9 & 19.8 \\
\hline \multicolumn{4}{|l|}{ Indigenous ethnicity } \\
\hline No & 9750 & 13372.2 & 89.3 \\
\hline Yes & 1151 & 1600.5 & 10.7 \\
\hline \multicolumn{4}{|c|}{$\begin{array}{l}\text { * Includes data from } 10901 \text { children } \\
\text { ₹ Mean of socioeconomic status index }\end{array}$} \\
\hline
\end{tabular}

of overweight and obesity $(26.6 \%$ and $25.6 \%$, respectively). A multivariate model that included the covariates region, area, sex, maternal schooling, indigenous ethnicity, socio-economic status and age showed that there were no significant difference in the odds of being overweight by region of the country, or between urban and rural populations. Female children had higher odds of obesity than male (OR=1.26, 95\% CI1.10, 1.45). The analysis showed that the risk for overweight and obesity was positively associated with maternal schooling and socioeconomic status. Bivariate analysis showed that the absence of a native language speak- ing woman in the household was a risk factor for obesity $(\mathrm{OR}=1.86,95 \% \mathrm{CI} 1.41,2.46)$, although a lower estimate was obtained after adjusting for the remaining variables in the model (OR $=0.91,95 \%$ CI $0.67,1.23)$ (Table II). We found a significant positive association between age and the prevalence of overweight and obesity (OR=1.05, 95\% CI 1.02, 1.09), as presented in Figure 1. In this figure we can also see that the mean BMI also follows an increasing trend with age. Similar models were fitted using father's literacy instead of maternal schooling as covariate. After adjustment for other covariates in the model, father's literacy was positively associated with the risk for overweight and obesity in children (OR=1.44, 95\% CI 1.07, 1.95), without modifications in the association estimates of the other covariates in the multivariate model.

Multivariate models to explore factors associated with obesity and overweight were fitted by region to assess the presence of differential risk factors associated with overweight and obesity in each region. Overall, the multivariate model results for the country were consistent for each region. The only differences observed were a greater risk of overweight and obesity among girls and a greater risk for obesity associated with higher maternal schooling in the South compared with other regions (data not shown). For Mexico City it was not possible to assess the effect of urban or rural residence or the presence of a native language speaker in the household, due to the small number of rural or native language speaking woman in the population of that specific region.

\section{Discussion}

This study provides the first evidence of the prevalence estimates of overweight and obesity in children 5-11 years of age in Mexico, using data from a representative National Nutrition Survey (NNS-1999). At the country level, results show that about one of every five school-age children are overweight or obese. The risk for obesity was higher in girls than in boys. Similarly, the prevalence of overweight and obesity was positively associated with father's literacy status, maternal schooling, as well as with children's age. The prevalence figures of overweight and obesity in this study may be compared with those reported in countries like Chile, Brazil, United States, and Cuba. ${ }^{29-31}$

Father's schooling has been shown to be a risk factor for the presence of overweight and obesity in children. Previous studies conducted in the Mexican population have documented an association between the father's schooling and obesity in children $<5$ years of age. ${ }^{10}$ In the present study a positive association was 
Table II

Prevalence rates, Crude and adjusted* odds ratios of OVerWeight and obesity, by Characteristics Of ChILDRen 5 to 11 years old in the National Nutrition Survey, Mexico, 1999, using the Cole reference population ${ }^{2,3}$

\begin{tabular}{|c|c|c|c|c|c|c|c|}
\hline \multirow[b]{2}{*}{ Variable } & \multirow{2}{*}{$\underset{N}{\text { Sample }}$} & \multirow{2}{*}{$\begin{array}{l}\text { Population estimate } \\
\text { (thousands) }\end{array}$} & \multirow{2}{*}{$\begin{array}{c}\text { Prevalence of } \\
\text { overweight and obesity }\end{array}$} & \multirow{2}{*}{$\begin{array}{l}\text { Cruce } \\
\text { OR }\end{array}$} & \multicolumn{3}{|c|}{ Adjusted* } \\
\hline & & & & & $95 \% \mathrm{Cl}$ & $O R$ & $95 \% \mathrm{Cl}$ \\
\hline$N$ ational & 10901 & 14972.6 & 19.5 & & & & \\
\hline \multicolumn{8}{|l|}{ Region } \\
\hline North & 3188 & 2657.4 & 25.6 & 2.18 & $1.81-2.63$ & 1.21 & $0.98-1.48$ \\
\hline Center & 3292 & 5001.4 & 18.0 & 1.33 & $1.11-1.60$ & 0.94 & $0.77-1.15$ \\
\hline Mexico City & 855 & 2287.0 & 26.6 & 2.19 & $1.72-2.79$ & 1.20 & $0.92-1.56$ \\
\hline South & 3566 & 5026.7 & 14.3 & & & & \\
\hline
\end{tabular}

\begin{tabular}{lrrrrrrr}
$\begin{array}{l}\text { Area of residence } \\
\text { Urban }\end{array}$ & 6142 & 10339.6 & 22.9 & 2.21 & $1.91-2.55$ & 1.08 & $0.92-1.28$ \\
\hline Rural & 4759 & 4633.0 & 11.7 & & & & \\
Sex \\
Female & 5505 & 7618.7 & & & & & \\
\hline Male & 5396 & 7353.9 & 21.2 & 1.25 & $1.09-1.43$ & 1.26 & $1.10-1.45$ \\
\hline
\end{tabular}

\begin{tabular}{|c|c|c|c|c|c|c|c|}
\hline \multicolumn{8}{|l|}{ Maternal schooling } \\
\hline Elementary school & 5087 & 6368.6 & 17.6 & 1.57 & $1.27-1.94$ & 1.18 & $0.94-1.46$ \\
\hline Middle school & 1839 & 2880.5 & 25.6 & 2.24 & $1.99-3.24$ & 1.41 & $1.08-1.85$ \\
\hline High school or more & 1560 & 2763.6 & 25.6 & 2.53 & $2.00-3.21$ & 1.32 & $1.01-1.73$ \\
\hline No schooling & 2415 & 2959.9 & 12.0 & 1 & & & \\
\hline \multicolumn{8}{|l|}{ Indigenous ethnicity } \\
\hline No & 9750 & 13372.2 & 20.4 & 1.86 & $1.41-2.46$ & 0.91 & $0.67-1.23$ \\
\hline Yes & 1151 & 1600.5 & 12.1 & 1 & & & \\
\hline Socio-economic status & 10901 & 14972.6 & & 1.76 & $1.63-1.89$ & 1.62 & $1.47-1.78$ \\
\hline
\end{tabular}

found between maternal schooling and father's literacy, as well as higher prevalence estimates of overweight and obesity among school-age children.

It should be emphasized that the socioeconomic status and maternal schooling were associated with obesity after adjusting for potential confounders in the multivariate analysis, thus showing an independent association with obesity. The positive association between socioeconomic status and the prevalence of obesity may be related to more sedentary lifestyles and changes in diet in higher socioeconomic strata.

Conversely, the absence of a native language speaking woman in the household was positively associated with obesity in the crude analyses. This effect vanished in the multivariate models, thus suggesting that the risk factor is not the absence of a native language speaking woman in the household but rather some other related variables (maternal schooling, or socioeconomic status) that are positively associated with overweight and obesity in school-age children.

Some limitations stemming from the NNS-1999 design and sample size should be considered when interpreting the results of this study. It is a cross-sectional survey; therefore, we cannot make causal inferences relating obesity and overweight with the exposure variables analyzed. A more precise measurement of the children's body composition was not possible due to increasing costs. The BMI was used as a low-cost body composition indicator since it has a high correlation with the amount of body fat. ${ }^{32}$ Measuring 


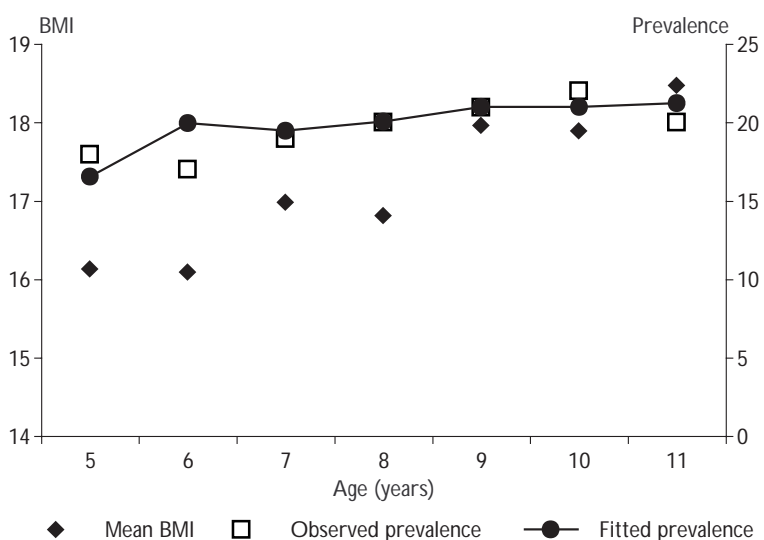

Figure 1. Mean BMI, observed and fitted Prevalence* OF OVERWEIGHT AND OBESITY BY AGE, MEXICAN CHILDREN 5 to 11 years old, National Nutrition Survey, MeXico, 1999

the height of children involves some complexity that may be a further limitation; however, in the NNS-1999 weight and height were measured by standardized surveyors using international guidelines. ${ }^{25,26}$

Several authors have been concerned with the behavior of weight-for-height standards in school-age children and have strived to design an alternative index to improve the proper assessment of nutritional status. $^{33}$ The BMI was used as an indicator of overweight and obesity in the NNS-1999 and following the recommendations of the International Obesity Task Force we selected a reference population proposed by Cole et al. ${ }^{23}$ Other options of reference populations that have been proposed to define obesity are the American $^{34}$ and the French ${ }^{35}$ populations. The former is based on a population with a greater prevalence of overweight and obesity that has been widely used as a reference population; the latter population has a lower prevalence of overweight and obesity, and its use has been recommended by a panel of experts assembled by WHO. ${ }^{33}$ However, we selected the standard proposed by Cole et al. because it is based on data from several countries, which allows international comparisons, and also presents specific age and sex centiles for children linked to adult cutoff points of overweight and obesity associated with adult disease.

The NNS-1999 is a representative sample of the four regions and urban and rural areas of the country. However, it is not a representative sample at the state level for all the states of the country, thus precluding the possibility of making inferences at the state, municipal, or local levels. By design, the survey sample did not include the rural area of Mexico City. It is important also to note the small number of households with indigenous dwellers, after stratifying by region or by area, which made difficult to estimate odds ratios for obesity and made the estimates unstable. A further limitation of the study is that it was not possible to control for maturation effects. After 5 years of age, part of the variability in growth is due to maturation events occurring in children at different ages. Early and late maturation factors have been described with more definite differentiation occurring after 5 or 6 years of age. Even among healthy children, there is an important variation on the maturation process. An early maturation can be related to an increased risk of obesity. ${ }^{33}$ Not including the extent of maturation in children may result in variation of our indicators if maturation events differ by country regions or by sex. A final limitation of the study is the presence of potential confounders that were not included, such as diet and physical activity or inactivity in children, or the parents' body composition. Due to the size of the study we were able to gather information on those variables only in a subsample of school-age children, not representative at the country level. It may be possible that differences in the prevalence of obesity found in this study by region or area reflect differences in diet or physical activity patterns of school-age children residing in those regions or areas. As for the case of parent's body composition, the NNS-1999 collected data on weight and height on a subsample of women of reproductive age. However, only in a limited number of cases is there information about school-age children and their mothers. The reduced sample size of this group did not allow us to conduct statistical analysis with an acceptable power, and therefore this was not carried out.

The present survey is the first study conducted in school-age children, filling a gap of information on the nutritional status of Mexican school-age children. Study findings show that overweight and obesity is an increasing public health problem in Mexico, calling for the formulation of health policies and preventive programs in this population group.

\section{Acknowledgments}

We acknowledge the collaboration of the Instituto Nacional de Salud Pública, the Secretaría de Salud and the Instituto Nacional de Estadística, Geografía e Informática in the design and implementation of the National Nutrition Survey 1999. Dr. Ignacio Méndez 
assisted with the statistical analyses and Dr. Eduardo Velasco reviewed the final edition of this paper.

\section{References}

1. N ational Research Council. Committee on diet and health food and nutrition board. Commission on life sciences. D iet and health. Implications for reducing chronic disease risk. W ashington, DC: N ational A cademy Press, 1989.

2. Seidell JC 0 besity in Europe: Scaling and epidemic. Int I 0 bes Relat Metab Disord 1995;19(3P):S1-4.

3. G aluska DA, Serdula M, Pamuk E, Siegel PZ, Byesr T.Trends in overweight among US adults from 1987 to 1993:A multistate telephone survey. Am J Public Health 1996;86:1729-1735.

4. Hodge AM, D owse GK, Gareeboo H,Toumilehto J, Alberti KG, Zimmet PZ. Incidence, increasing prevalence and predictors of change in obesity and fat distribution over 5 years in the rapidly developing population of Mauritius. Int J 0 bes Relat Metab Disord 1996;20:137-146.

5. De 0 nis $M$, Blösnner M. Prevalence and trends of overweight among preschool children in developing countries. Am J Clin N utr 2000;72:1032-1039.

6. Troiano RP, Flegal KM, Kuczmarski RJ, C ampbell SM, Johnson CL. $O$ verweight prevalence and trends for children and adolescents. The $\mathrm{N}$ ational Health N utrition Examination Surveys, 1963 to 1991.Arch Pediatr Adolesc Med 1995;149:1085-1091.

7. Chinn S, Rona RJ.Trends in weight-for-height and triceps skinfold thickness for English and Scottish children, 1972-1982 and 1982-1990. Pediatr Perinat Epidemiol 1984;8:90-106.

8. Lehingue Y, Picot MC, Millot I, Fassio F. Accroissement de la prévalence de l'obésité chez les enfants de 4-5 ans dans un département français entre 1988 et 1993. Rev Epidemol Sante Publ 1996;44:46-47.

9. Sepúlveda-A mor J, Lezana MA,Tapia-C onyer R,Valdespino JL, Madrigal $H$, Kumate J. Estado nutricional de preescolares y mujeres en México: resultados de una encuesta probabilística nacional. Gac Med Mex 1990:126:207-224.

10. Hernández B, Peterson K, So bol A, Rivera J, Sepúlveda J, Lezana MA. Sobrepeso en mujeres de 12 a 49 años y menores de cinco años en México. Salud Publica Mex 1996;38:178-188.

11.A lbala C, Vío F. 0 besidad y pobreza: un desafío pendiente en Chile. En: Peña M, Bacallao J, ed. La obesidad en la pobreza: un nuevo reto para la salud pública.W ashington, D C: O PS, 2000;Publicación Científica N 0.576. 12.W iecha J, C aseyVA. High prevalence of overweight and short stature among $\mathrm{H}$ ead Start children in Massachusetts. Public Health Rep 1994;109(6):767-773.

13.W HO, N UT, N CD. 0 besity. Preventing and managing the global epidemic. Report of aW HO Consultation on 0 besity. Geneva:W HO, 1997:17-40.

14. González-Villalpando C, Stern MP. La obesidad como factor de riesgo cardiovascular en México. Estudio en población abierta. Rev Invest Clin 1993;45:13-21.

15. Avila A, Chávez A, Shamah T. Encuesta U rbana de Alimentación y Nutrición en la Zona Metropolitana de la Ciudad de México (EN URBAL-1995). México, DF: IN N SZ, 1995.
16. Toussaint MG . Patrones de dieta y actividad física en la patogénesis de la obesidad en el escolar urbano. Bol Med Hosp Infant Mex 2000;57(11):650-662.

17. Hernández B, Gortmaker SL, Colditz GA, Peterson KE, Laird N M, Parra-C abrera S. Association of obesity with physical activity, television programs and other forms of video viewing among children in Mexico City. Int J 0 bes 1999;23:845-854.

18. Repáraz F, Chueca M, Elcarte R, Iñigo J, 0 yarzábal M,Villa. 0 besidad infantil en $\mathrm{N}$ avarra: evolución, tendencia y relación entre obesidad infantil y adulta. Estudio PEC N A. 1987-1993. An Sist Sanit N avar 1998;21(3):293-300.

19. N ational Institutes of Health. C onsensus D evelopment Panel on the health implications of obesity. Ann Intern Med 1985;103:1073-1077. 20. Hubert H, Feinlib M, MCN amara P. 0 besity as an independent risk factor for cardiovascular disease:A 26-year follow-up of participant in the Framingham heart study. Circulation 1983;67:968-974.

21. Elcarte R,Villa-Alizaga Y, Sada J. Estudio de N avarra (PEC N A). Hiperlipidemias. ¿C uál es la mejor definición de hiperlipidemias en la edad infarto-juvenil? An Esp Pediatr 1993;38:317-322.

22. Lew EA. Mortality and weight: Insured lives and the American Cancer Society studies. Ann Intern Med 1985;103(6):1024-1028. 23. Cole TJ, Bellizzi MC, Flegal KM, D ietz W H. Establishing a standard definition for child overweight and obesity worldwide: International survey. BMJ 2000; 320:1240-1243.

24. Bronfman M, G uiscafré H, Castro V, Castro R, Gutiérrez G. La metodología y análisis de las características socioeconómicas de la muestra. Arch Invest Med 1988;19:351-360.

25. Lohman TG, Roche AF, Martorell R, Ed.Anthropometric standardization reference manual. Champaign (IL): Human Kinetics Books, 1988.

26. Habicht JP. Estandarización de métodos epidemiológicos cuantitativos sobre el terreno. Bol 0 ficina Sanit Panam 1974;76:375-385.

27. StataC orp. Stata Statistical Software: Release 7.0. College Station

(TX): Stata Corporation, 2001.

28. SPSS for W indows.V. 10.0.0 Chicago (IL): SPSS Inc. Statistical Program for Social Sciences, 1999. Available from: http://www.spss.com/ 29. Ministerio de Salud de Chile. Informe del Ministerio de Salud. Santiago de Chile: Ministerio de Salud 1998.

30.W ang Y, Monteiro C, Popkin BM. Trends of obesity and underweight in older children and adolescents in the United States, Brazil, China and Russia.Am J C lin N utr 2002; 75:971-977.

31. Porrata C, Suárez A, Hernández M, Jiménez S, A rgüelles J, C abrera A. Dieta y salud en Cuba.Arch Latinoam N utr 1995;45(1-S):214-219.

32. Dietz W, Bellizzi M. Introduction:The use of body mass index to assess obesity in children. Am J C lin N utr 1999;70:123S-125S.

33. W orld Health 0 rganization. Physical status:The use and interpretation of anthropometry: Report of aW HO Expert Committee. Geneva:W H0; 1994; Tech Rep Ser 854.

34. Must A, D allal GE, Dietz W H. Reference data for obesity, $85^{\text {th }}$ and $95^{\text {th }}$ percentiles of body mass index $\left(\mathrm{wt} / \mathrm{ht} \mathrm{t}^{2}\right) æ$ and triceps skinfold thickness. Am J C lin N utr 1991;53:839-846. Am J C lin N utr (correction) 1991;54:773.

35.Rolland-C achera MF, Cole TJ, Sempe M,Tichet J, Rossignol C, Charraud A. Body mass index variations: $C$ entiles from birth to 87 years. Eur J Clin N utr 1991;45(1):13-21. 